\title{
Participatory disease surveillance (PDS) of sheep and goats diseases in selected districts of Afar Re- gional State: Particular focus on Pestes des petit ruminants (PPR) and Sheep and goat pox disease (SGP)
}

\author{
Getachew Gari ${ }^{1}$, Gedlu Mekonnen ${ }^{2}$, Demeke Sibhat ${ }^{1}$, Ashebir Abebe ${ }^{1}$, Mesfin Sahle ${ }^{1}$, \\ Getnet Abie \\ ${ }^{1}$ National Animal Health Diagnostic and Investigation center (NAHDIC), Jimma road, near \\ Meta-Abo Brewery, PO Box 04, Sebeta, Ethiopia. \\ ${ }^{2}$ Food and Agricultural Organization of the United Nation, Sub-regional Office for East Africa, \\ Addis Ababa.
}

Corresponding author: Getachew Gari, getachewgj@yahoo.com, NAHDIC, PO Box 04, Sebeta.

\section{Abstract}

Participatory disease surveillance uses a participatory technique for the collection of qualitative epidemiological information within the community observations and existing veterinary knowledge. Participatory disease surveillance wasconductedto assess and prioritize the majordiseases of sheep and goat in selected districts of Afar Regional statefrom July to September 2012 andspecifically to understand the status of PPR and SGP diseases. Three Kebeles from each district were selected out of four districts based on representativeness and a total number of twelve Kebeles were selected. Elite informantswereselected purposivelyto collect in-depth informationand 10 to 12 community informants were included in each PDS process.A total of 500 sera samples were also tested for antibody against PPR virus using competitive Enzyme Linked Immuno-Sorbent (C-ELISA). The informants ranked the livestock species based on the economic value fortheir livelihoodas goats, camel, cattle, sheep, donkey and chickenfrom the top priority to the least in descending order.Among listed diseases, respiratory syndrome/CCPP, SGP and tick and tick-borne diseases for goats and respiratory syndrome, diarrhea syndrome, tick infestation and SGP diseases for sheepwere the most priority disease problems top ranked by proportional piling. PPR outbreak was reported in Chifra district and the informants ranked among the top priority disease in goats. High sero-prevalence of antibody against PPR 78\% (95\%CI: 74.4-81.6) was detected in the study population which might be from natural infectionor PPR vaccination carried out in all districts. The sero-prevalence in goats was higher than in sheep $84.1 \%$ and $70.7 \%$, respectively. In conclusion, the priority disease problems identified should be given due attention and further epidemiological studies are required to gener- 
ate information used for the future control endeavor.

Keywords: Afar,Goat, Participatory disease surveillance, Sheep, PPR, Sheep and goat pox disease.

http://dx.doi.org/10.4314/evj.v19i1.8

\section{Introduction}

Sheep and goat populations in Ethiopia are estimated to be 25.5 million and 22.78 million, respectively (CSA, 2010/11). The distribution of sheep population across different agro-ecology was reported to bean even distribution between highlands and lowlands but goat populations arefound more dominant in the lowland areas of the country (Akliluand Catley, 2010). Sheep and goats contribute $25 \%$ of the domestic meat consumption; about $50 \%$ of the domestic wool requirements; about $40 \%$ of fresh skins and $92 \%$ of the value of semi-processed skin and hide export trade. It is estimated that 1,078,000 sheep and 1,128,000 goats are used in Ethiopia for domestic consumption annually. The current annual off-take rate of sheep and goatsis 33\%and 35\%, respectively (Adane Hirpa and Girma Abebe, 2008). There is also a growing export market for sheep and goat meat and live animal export. In 2010/11, the export value from sheep and goat's meat and live animal were about 63 million and 148 million USD, respectively (USAID, 2011).

Sheep and goat populations in Zone 1 and Zone 3 of Afar Regional state are estimated to be 990thousands and 1.77 million, respectively (CSA, 2010/11). Pastoralists have high priority and adapted to produce small ruminants due to the impact of successive droughts, conflicts or new market demands. In terms of rebuilding herds afterdrought, pastoralists tend to first rebuild sheep and goat flocks before acquiring cattle or camels (Jacob Aklilu and Catley, 2010). Small ruminants reproduce faster than larger species, and then are converted into cattle and camels if and when the opportunity arises. Small ruminantproduction requires less investment and they are the most suitable pro-poor wealth group.

Participatory epidemiology is an emerging field that is based on the use of participatory techniques for the collection of qualitative epidemiological information contained within the community observations, existing veterinary knowledge and traditional oral history (Mariner and Paskin, 2000). The extent of community knowledge on a particular agricultural activity is usually related to the degree of economic dependence a society has on that activity. Concerning livestock, existing veterinary knowledge of pastoral and agro-pastoral com- 
munities are the best source of traditional livestock knowledge. Participatory disease surveillance (PDS) has also an advantage to build on what local people already know; enables them to use their own knowledge and skills in disease surveillance and control.Participation is a tool for empowerment of the local community, particularly of the poor and of rural women (Catley, and Birhanu Admassu, 2003).

The monthlypassive disease reporting frequency and the quality of report collected at national level from Afar Regional state in 2011 showed that it was one of the least reporting as compared to other regional states (Annual year book of Epidemiology, APHRD, 2011). Owing to this fact, surveillance using quick and feasible methods like participatory disease surveillance (PDS) is indispensable to understand the status of major transboundary infectious diseases and prioritize the disease problems for decision making process. The general objective of this study was to backstop the information gaps and also transfer the PDS technique to the local veterinary professionals for further exercise if the need arises by the regional decision makers in the future.Theobjectives of the study were to prioritize the major diseases of sheep and goat in selected districts of Afar Regional state based on producers perception in participatory manner and to understand the status of PPR and SGP diseases through PDS technique and serological detection ofantibody against PPRvirus to enlighten further epidemiological study andfuture control endeavor.

\section{Materials and Methods}

\section{Description of the study area}

Afar regional state is located in the north-eastern part of Ethiopia where the most majority part of the regionalstate lies in the great rift valley of the Ethiopian segment. The moisture stressed arid and semi-arid lowland climate of the region favors the pastoral livestock production system. Agricultural activities are evolving around the Awash river bankusing irrigation scheme and the western escarpment where the climate is in the transition to the highland agro-climate. In general livestock production is the basis for the livelihood of Afar region with $90 \%$ population engaged in pastoral, 5\% agro-pastoral and 5\% other occupations (Afar Region Metrological study, 2003). Livestock production is the source of food, income, capital asset and social prestige. Afar regional state comprised of five administrative zones and Argoba special district, among which the largest livestock populations are found in Zone 1 and Zone 3 
administrative zones (Figure 1).Livestock population in selected four districts (two districts from each Zone-1 and Zone-3) is shownin Table 1.

Table 1: Livestock population in the selected districts

\begin{tabular}{llccccc}
\hline No & Spp of animal & Chifra & Ada'ar & Amibara & $\begin{array}{c}\text { Awash } \\
\text { Fentale }\end{array}$ & Total \\
\hline 1 & Cattle & 352346 & 352316 & 103959 & 86085 & 894,706 \\
2 & Sheep and goats & 649006 & 649006 & 170569 & 119080 & $1,587,661$ \\
3 & Camel & 126349 & 126349 & 39995 & 41245 & 333,938 \\
4 & Equine & 24977 & 24977 & 3885 & 2653 & 56,492 \\
& TOTAL & 1152678 & 1152648 & 318508 & 249063 & $2,872,897$ \\
\hline
\end{tabular}

Source: CSA, 2011/12

\section{Study methods}

The study was conductedfrom July to September 2012 and thestudy team organized trainingfor regional and districtveterinary staffs involved in the surveillance tofacilitate the participatory disease surveillance (PDS) techniques and tools.

Participatory appraisal is largely based on qualitative techniques of gathering animal health information. Two important principles whichwere designed to improve the quality and reliability of the information, Triangulationand Flexibility, were used. Triangulationis the method in which information is gained from several intentionally different perspectives. Flexibility in the appraisal is an essential principle where the techniques were not rigidly preplanned and executed without deviation, but used unstructured questions that can be changed at any point during the investigation. A number of data sources were tapped in the triangulation principles. 


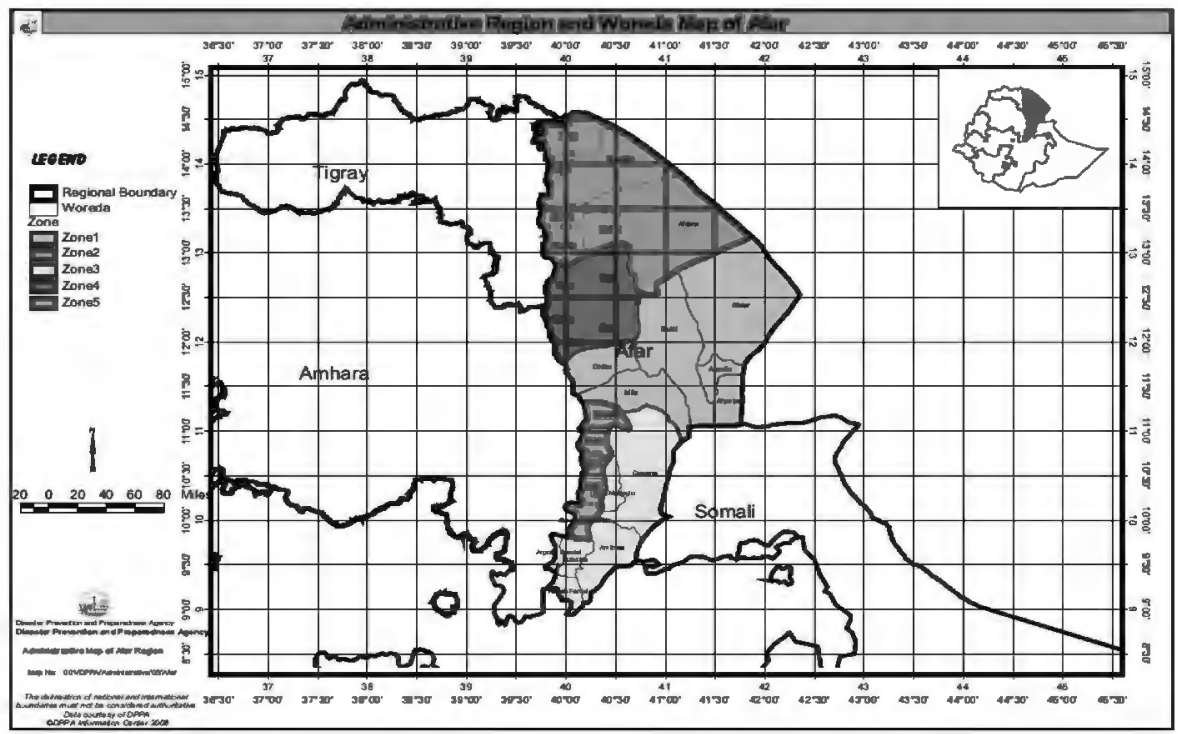

\section{Figure 1: Map of Afar Regional state}

Source: Data courtegy from Disaster Prevention and Preparedness Agency (DPPA), 2006.

The checklist questions for the interview were aimed to capture data about types of livestock,purpose of keeping livestock, major disease problems in their area, list of sheep and goats diseases, and clinical symptoms of those ranked diseases. PDS tools such as ranking, proportional piling,matrix scoring and disease seasonality were applied to set priorities and rank.Ranking types of livestock was based on their abundance and economic importance which could be the value for their livelihood and social prestige. Matrix scoring was applied to validate the information collected on each disease against their major clinical symptoms.

Appropriate sensitization wascreated on the objective of the PDS work to the Regional and district Pastoral Agriculturerelevant officials in order to get proper supportin their respectivearea. The study team trained focal person ateachselected district and Regional Bureau (five veterinary personnel)on the PDS technique for five days tocoordinateand facilitatethe PDS work in their respective area. 


\section{Selection of the study districts and Kebeles}

The selection of the study districts was carried out in consultation with the regional Pastoral Agriculture Bureau expert with the knowledge of high sheep and goats population, the presence of veterinaryservice in the districts and of course some consideration was given for representativeness of the districtsin their geographical location for the other parts of the region. Two districts were selected from each zone (Zone 1 and Zone 3) and the selection of the Kebele(the lowest administrative level in Ethiopia) in each district was determined in discussion with the district Pastoral Agriculture office experts(Figure 2). Three Kebeles were selected from each district andthe total number of selected Kebeles was twelve (Table 2).The selectionofelite communitykey-informants and informants were purposive which was essential to collectin-depth information on a number of issues.

Table 2:Study zones, districts and Kebeles.

\begin{tabular}{lll}
\hline Administr. Zones & Districts & Kebeles \\
\hline Zone 1 & Chifra & Jara,Anderkelo, Mesgido \\
& Adaar & WantuFursi, Waranso, Jeldu \\
Zone 3 & Amibara & Bonta, Alaydegie, Werer \\
& Awash Fentale & Dohoo, Sabure, kebena \\
\hline
\end{tabular}

The optimum and manageable size of informants and key-informants recommended in the PDS interview are assumed to be 10-15 persons (Mariner and Paskin, 2000) and thus, twelve informants were determined in each Kebele. Community groups such as traditional leaders, religious leaders, traditional healers, community animal health workers, Kebele representatives, and agricultural development agents were included in the informants. 

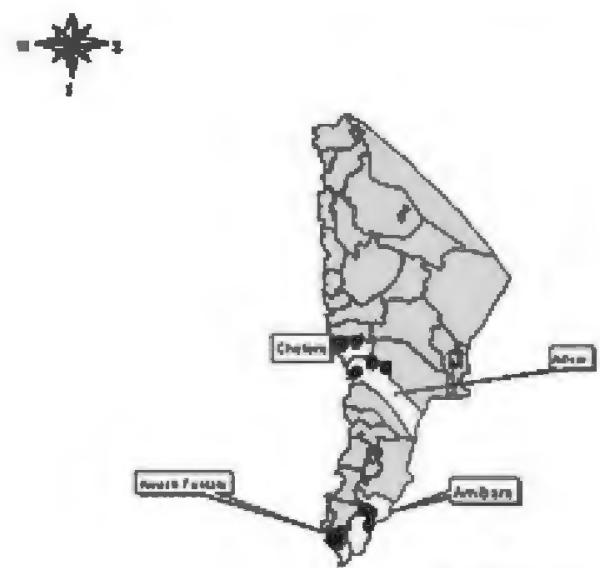

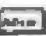

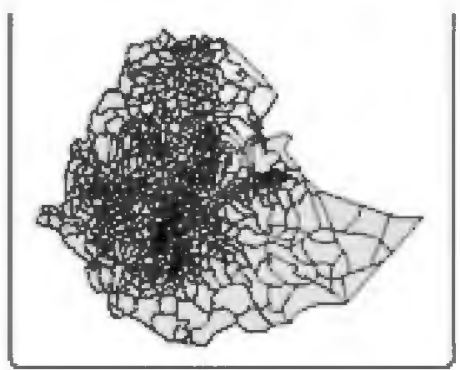

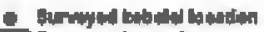

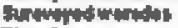

Wonth

at

t

2to

Ho kwa

Figure 2: Selected districts and Kebelelocations in Afar regional state

\section{PDS interview process and data collection}

The number of appraisal team was three in all PDS exercises (one moderator, one translator and one record keeping person). The convenient time and place of meeting was determined in consultation with the key informants. The moderator kicks off the meeting by introducing the appraisal team members and then invited all the participants to introduce themselves. After explaining a brief account on the objective of the meeting, the interview process often started with simple and general questionsguided by the checklist in order to keep theflow of idea.The opportunity for flexibility during the interview process wasmaintained throughout the process to obtain the required information. In most cases all the participants were allowed to give their opinion to the interview questions to avoid the over dominance of few key informants. When the response to the question requirescomparison and semi-quantitative measurements,we used analytical tools such as ranking, proportional piles and matrix scoring. While applying these analytical tools, first thorough description was given on the subjects, theinformants weresub-divided into three units 
to avoid individual over dominance, personal bias and to improve statistical efficiency of the data obtained (Figure 3 and 4). All information discussed during the interview was recorded. The interview process lasted maximum two hours. Assessing for sheep and goats diseases was done separately in every PDS process. After complete list of the diseases and syndromes recovered, proportional piling method was used to prioritize the diseases according to their economic importance. The community perception on the economic importance of a disease is related with its morbidity, mortality, production losses and zoonotic importance. Each sub-group was given 100 stone beads to pile proportionallyaccording to the importance of each disease. Veterinaryservice delivery system, availability of conventional drugs and vaccines in clinics and drug stores, the role of CAHWs in contribution to Vet. Service delivery system and traditional disease information communication("Afar Dagu”) were also assessed during the PDS process.

Duringthe course of the interview, probing questions were used to validate and gather more details on the topics and to improve the quality of information gathered. Probing questions were also important to verify the internal consistency of information. Triangulation of the appraisal information with secondary data sources was also conducted to validate the information. Secondary data from district veterinaryclinicsand expert opinion were gathered to cross check the data.

Visual observation of the study Kebele and biological sampling were also conducted. In each Kebele 40 serum samples (20 from each sheep and goats) were collected to support the appraisal information through serological result. A total of 500 serum samples were tested using competitive Enzyme Linked Immuno-Sorbent (C-ELISA) assay. Both sex and age groups were included. Young age group was between 6 month and one year whereasadult is above one year. 


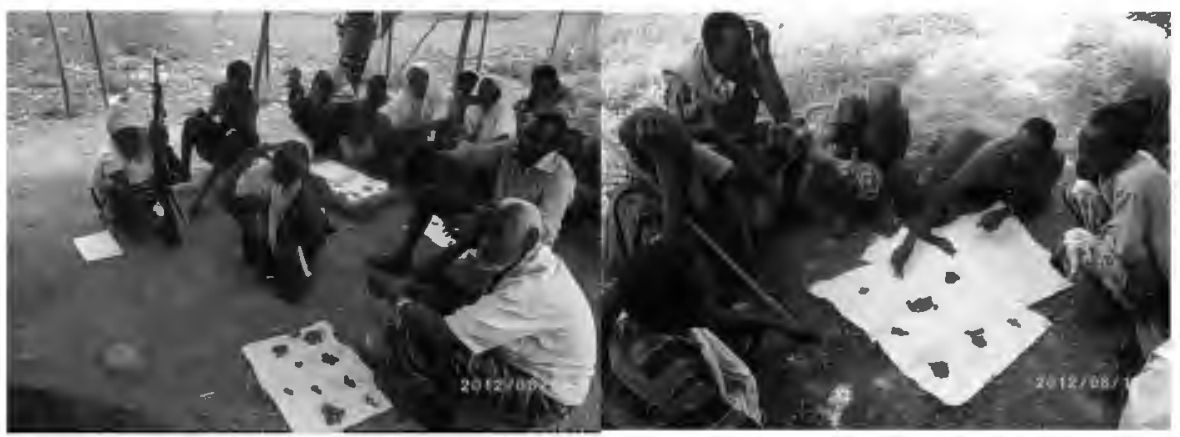

Figure3: Community informant's dis- Figure 4: Community informants in cussing and sharing their knowledge the process of exercising proporduring the PDS process tional piling to prioritize sheep and goats diseases

The overall agro-ecological feature of the study areas, the potential risk factors for the occurrence of the disease, grazing areas and water sources for the livestock were recorded during the transect visit through the Kebeles. The data was summarized in tables and graphs.

\section{Results}

\section{Types of Livestock and their economic importance}

The informants declared types of livestock reared in the study area as camel, cattle, sheep, goats, donkey, and chicken. In each kebele they ranked animal species based on their perception of abundance and also based on their economic value for their livelihood. Although slight variation exists in the perception of the informants across the kebeles, they ranked the highest population size as goats, sheep, cattle, camel, donkey and chicken in descending order(Table 3). However, the priority ranking on the economic value from the highest to the least was goats, camel, cattle, sheep, donkey and chickenin descending order. There were interesting arguments and justificationsto rank goats or camels at the topeconomic value animal and the following arguments were discussed.

Those informants who ranked goats as a top priority economic value for their livelihood argued that goats can resist drought more than cattle and sheep; milking goats are like mother breast for children; goats milk and butter are 
believed to have medicinal value; can give birth two times in a year; goats are a quick source of money for the family expenditure; source of meat for family consumption and for honored guest; goats are often used for different social affairs like offering; hide from goat is used for making water-bag and prayer mat.

On the other hand, those informants who ranked camel as a top economic value argued that camel doesn't die during drought but it is the only animal that can give milk during drought period. Camel can give milk three times a day and declared that milk volume from one camel is equivalent to 50 milking goats. They assumed that the economic value of one camel is almost comparable with 30 goats. Camel is used for the transport of all goods necessary for their livelihood; camel meat is believed to have medicinal value and has longstanding historical legend with pastoral community.

Table 3: Ranking Livestock number based on their perception and economic importance.

\begin{tabular}{llccccc}
\hline \multicolumn{5}{c}{ Livestock spp ranked based on estimated number } \\
\hline No & Animal types & Chifra & Ada'ar & Amibara & $\begin{array}{c}\text { Awash } \\
\text { Fentale }\end{array}$ & Mode \\
\hline 1 & Camel & 4 & 3 & 4 & 3 & 4 \\
2 & Cattle & 3 & 3 & 2 & 2 & 3 \\
3 & Sheep & 2 & 2 & 3 & 4 & 2 \\
4 & Goats & 1 & 1 & 1 & 1 & 1 \\
5 & Donkey & 5 & 5 & 5 & 5 & 5 \\
6 & Poultry & - & - & - & 6 & 6 \\
& & Livestock ranked based on economic importance & \\
1 & Camel & 1 & 2 & 3 & 2 & 2 \\
$\mathbf{2}$ & Cattle & 2 & 3 & 2 & 3 & 3 \\
$\mathbf{3}$ & Sheep & 3 & 3 & 4 & 4 & 4 \\
4 & Goats & 4 & 1 & 1 & 1 & 1 \\
$\mathbf{5}$ & Donkey & 5 & 5 & 5 & 5 & 5 \\
$\mathbf{6}$ & Poultry & - & - & - & 6 & 6 \\
\hline
\end{tabular}

\section{Major livestock production constraints}

The main constraints in livestock production discussed in respective districts were as follows: 
Drought, tick and tick borne diseases, Parthynium weed which invaded and destroyed tremendous grazing lands and bloat was blamed as an emerging problem which caused death of many cattlein recent days.

\section{Diseases of Sheep and goats assessed and prioritized}

Major infectious and non-infectious disease problems within the knowledge scope of the informants were assessed through the interview question. Types of diseases occurring in the area were listed as declared by the informants with the clinical definitions and local name (Vernacular name) of the diseases. Vernacular name of some diseases slightly vary from one district to another and all the different names were recorded for cross-checking purpose. The corresponding scientific name of these diseases was also given based on the clinical manifestations declared by the informants. Some diseases were reported all across the districts, but other diseases were specificto one or two districts. List of the diseases and syndromes, their vernacular name and clinical description recovered for goats are seen in table (4) and the corresponding that of sheep is in table (5).

Table 4: List of diseases affecting goatsas declared by informants, the vernacular names and scientific names and clinical descriptions:

\begin{tabular}{|c|c|c|c|c|}
\hline No & $\begin{array}{l}\text { Vernicular } \\
\text { name }\end{array}$ & Scientific name & $\begin{array}{l}\text { Clinical description of the disease } \\
\text { as declared by the informants }\end{array}$ & Differential $\mathrm{dx}$ \\
\hline 1 & Sandera & $\begin{array}{l}\text { Orf (Contagious } \\
\text { Ecthyma) }\end{array}$ & $\begin{array}{l}\text { Hard wart like lesion around } \\
\text { mouth, ears, perineum, udder/ } \\
\text { testicle. Highly transmissible } \\
\text { and sometimes the wound } \\
\text { bleeds.Doesn't respond to } \\
\text { oxytetracycline. }\end{array}$ & \\
\hline 2 & Agara & mange mites & $\begin{array}{l}\text { Hair mating, severe itching } \\
\text { around head and neck, affected } \\
\text { skin becomes dry and cracked, } \\
\text { and eventually could die. }\end{array}$ & \\
\hline 3 & Kos & Lameness & $\begin{array}{l}\text { A syndrome caused by tick (Kilim } \\
\text { /Iba'idu), thorn bush between } \\
\text { hooves or foot rot; unable to stand } \\
\text { with affected legs, swelling of } \\
\text { hooves, pus formation and doesn't } \\
\text { move with the flock }\end{array}$ & \\
\hline
\end{tabular}




\begin{tabular}{|c|c|c|c|c|}
\hline No & $\begin{array}{l}\text { Vernicular } \\
\text { name }\end{array}$ & Scientific name & $\begin{array}{l}\text { Clinical description of the disease } \\
\text { as declared by the informants }\end{array}$ & Differential $\mathrm{dx}$ \\
\hline 4 & Arawagit & Heartwater & $\begin{array}{l}\text { Affected goats raise head upside } \\
\text { and move crazy, circling, muscle } \\
\text { tremor, blowing, convulsion and } \\
\text { death }\end{array}$ & $\begin{array}{l}\text { Prosopisjuliflora } \\
\text { tree intoxication }\end{array}$ \\
\hline 5 & $\begin{array}{l}\text { Gublo/ } \\
\text { mesengele }\end{array}$ & $\begin{array}{l}\text { Contagious } \\
\text { CaprinePleuro } \\
\text { Pneumonia }\end{array}$ & $\begin{array}{l}\text { seek to be under shade, coughing, } \\
\text { relactant to move, abduct the } \\
\text { forelegs, depress head, rough } \\
\text { hair coat, salvation, ocular lesion, } \\
\text { decrease milk and inappetance }\end{array}$ & \\
\hline 6 & Wader-biyak & PPR & $\begin{array}{l}\text { Occurred during draught, } \\
\text { emaciation, highly transmissible, } \\
\text { haemorrhage in the visceral } \\
\text { organs, lacrimation, nasal } \\
\text { discharge, blindness, stomatitis. } \\
\text { The veterinary officer in Chifra } \\
\text { districtattested that it was an } \\
\text { outbreak of PPR and it was } \\
\text { considered as "New disease". }\end{array}$ & \\
\hline 8 & Abali & Haematuria & $\begin{array}{l}\text { Bloody urine, bloody diarrhea, } \\
\text { yellow color on carcass, in } \\
\text { conjunctiva, in sclera and on } \\
\text { tongue, black feces, transmissible } \\
\text { and fatal death }\end{array}$ & \\
\hline 9 & Surota & Pneumonia & $\begin{array}{l}\text { Coughing, nasal discharge and } \\
\text { can cure by treatment, occurs } \\
\text { during cold weather and rainy, }\end{array}$ & \\
\hline 10 & Undefeta & foot rot & $\begin{array}{l}\text { Occurs during high moisture, } \\
\text { lameness, severe lesion between } \\
\text { hooves, affects many goats during } \\
\text { that period, transmissible, }\end{array}$ & \\
\hline 11 & $\begin{array}{l}\text { Arabah/ } \\
\text { Funoyita }\end{array}$ & Bloat & Bloat due to unknown plants. & \\
\hline 12 & Abib & FMD & $\begin{array}{l}\text { Eroded wound around hooves and } \\
\text { in the mouth }\end{array}$ & \\
\hline 13 & Noke & $\begin{array}{l}\text { suspectedanapl } \\
\text { asmosis }\end{array}$ & $\begin{array}{l}\text { fever, rough hair coat, granting, } \\
\text { hyperaemicconjuctival mucous } \\
\text { membrane, dies when drink } \\
\text { water, bloody fluid in the } \\
\text { abdominal cavity (they call } \\
\text { it"malaria" of goats) }\end{array}$ & $\begin{array}{l}\text { Confirmation } \\
\text { required }\end{array}$ \\
\hline 14 & Adim/Arim & $\begin{array}{l}\text { Caseous } \\
\text { lymphadenitis }\end{array}$ & $\begin{array}{l}\text { Swelling under skin, move freely, } \\
\text { around mandible and pre- } \\
\text { scapular lymph node, contains } \\
\text { pus }\end{array}$ & \\
\hline
\end{tabular}


Table 5: List of diseases affecting sheepas declared by informants, the vernacular names and scientific names and clinical descriptions:

\begin{tabular}{|c|c|c|c|c|}
\hline No & $\begin{array}{l}\text { Vernicular } \\
\text { name }\end{array}$ & Scientific name & $\begin{array}{l}\text { Clinical description of the } \\
\text { disease as declared by the } \\
\text { informants }\end{array}$ & Differential dx \\
\hline 1 & $\begin{array}{l}\text { Foroda/Surota/ } \\
\text { Goson }\end{array}$ & $\begin{array}{l}\text { Bronchopnemonia } \\
\text { syndrome }\end{array}$ & $\begin{array}{l}\text { fever, coughing, nostrils } \\
\text { blocked with mucous, } \\
\text { emaciation, occurs } \\
\text { during drought, highly } \\
\text { transmissible, suckling lambs } \\
\text { get sick through milk and die }\end{array}$ & \\
\hline 2 & Undahe & $\begin{array}{l}\text { Diarrhea } \\
\text { syndrome/PPR }\end{array}$ & $\begin{array}{l}\text { Diarrhea, head swelling, } \\
\text { emaciation, highly } \\
\text { transmissible, tape worm } \\
\text { expelled with diahrrea, } \\
\text { lacrimation, blindness, nasal } \\
\text { discharge }\end{array}$ & \\
\hline 3 & Korboda & $\begin{array}{l}\text { Sheep and Goat } \\
\text { Pox }\end{array}$ & $\begin{array}{l}\text { Circular swelling on the } \\
\text { skin surface, on the face, } \\
\text { lacrimation, death }\end{array}$ & \\
\hline 4 & Abali/Asdaho & Haematuria & $\begin{array}{l}\text { Bloody urine, bloody } \\
\text { diarrhea, yellow color in } \\
\text { carcass, in conjunctiva, in } \\
\text { sclera and on tongue, black } \\
\text { feces, transmissible and fatal } \\
\text { death }\end{array}$ & \\
\hline 5 & Dubbele & $\begin{array}{l}\text { Septicemic } \\
\text { Pasteurollosis }\end{array}$ & $\begin{array}{l}\text { Oedematous swelling under } \\
\text { neck (Bottle neck), occurs } \\
\text { during drought, head } \\
\text { swelling, nasal discharge, } \\
\text { yellowish jell fluid comes out } \\
\text { from swelling on incision }\end{array}$ & \\
\hline 6 & Enkata/kanadi & Lice and fleas & $\begin{array}{l}\text { Suck blood, emaciation, weak, } \\
\text { segregate from the flock, and } \\
\text { occurs during drought }\end{array}$ & \\
\hline 7 & Sandera & $\begin{array}{l}\text { Orf (Contagious } \\
\text { Ecthyma) }\end{array}$ & $\begin{array}{l}\text { Hard wart like lesion around } \\
\text { mouth, ears, perineum, } \\
\text { udder/testicle, highly } \\
\text { transmissible and the wound } \\
\text { bleeds.Doesn't respond to } \\
\text { oxytetracycline. }\end{array}$ & \\
\hline 8 & Abib & FMD & $\begin{array}{l}\text { Wound around hooves and in } \\
\text { the mouth }\end{array}$ & \\
\hline 9 & Awul & Ceneorosis & $\begin{array}{l}\text { Circling, turn neck to side } \\
\text { and falls down }\end{array}$ & \\
\hline 10 & Migda & Malignant Oedema & $\begin{array}{l}\text { Swelling on the shoulder, } \\
\text { rough hair coat }\end{array}$ & \\
\hline
\end{tabular}




\begin{tabular}{|c|c|c|c|c|}
\hline No & $\begin{array}{l}\text { Vernicular } \\
\text { name }\end{array}$ & Scientific name & $\begin{array}{l}\text { Clinical description of the } \\
\text { disease as declared by the } \\
\text { informants }\end{array}$ & Differential $\mathrm{dx}$ \\
\hline 11 & Kilim/Iba'idu & tick infestation & $\begin{array}{l}\text { Lameness, emaciation, } \\
\text { transmit sanderaetc---. }\end{array}$ & \\
\hline 12 & Kirbi & liver fluke & $\begin{array}{l}\text { diarrhea, bottle neck, worm } \\
\text { inside the liver }\end{array}$ & \\
\hline 13 & Firah & Anthrax & $\begin{array}{l}\text { Non clotted blood comes } \\
\text { through mouth and nose }\end{array}$ & \\
\hline 14 & DegaMeka & Mineral deficiency & $\begin{array}{l}\text { Dwindling movement by the } \\
\text { hind legs and finally dies, }\end{array}$ & \\
\hline 15 & Bagidaria & $\begin{array}{l}\text { Gastrointestinal } \\
\text { parasites }\end{array}$ & $\begin{array}{l}\text { Emaciation, worm expelled } \\
\text { through diarrhea }\end{array}$ & \\
\hline
\end{tabular}

\section{Diseases of Goats}

Ranking of listed diseases using proportional piling in Chifra district showed that the top three diseases of goats were PPR, haematuria (Babesiosis) and CCPP (Table 6). The informants declared that PPR outbreak occurred about six months before this PDSin 2012 and subsequent control vaccination was carried out in chifra district. The local vets attested the outbreak but diagnosed only based on clinical manifestations. The most economically important goat diseases prioritized in Ada'ar district was Respiratory syndrome/CCPP, SGP and lameness. In Amibara district the informants ranked CCPP, Anthrax/Malignant eodema and Liver fluke as the top three priority diseases in goats. In Awash Fentale district, the informants ranked CCPP, diarrhea syndrome and SGP diseases as the top three priority diseases (Table 6). 
Table 6: Rank of common diseases of goats in selected districts using proportional piling.

\begin{tabular}{lcccc}
\hline & \multicolumn{3}{c}{ Proportional piling with 100 stones } \\
\cline { 2 - 5 } List of goats diseases & Chifra & Ada'ar & Amibara & Awash-Fentale \\
\hline Peste des Petit Ruminants (PPR) & 20 & 10 & 4 & 8 \\
CCPP/Respiratory syndrome & 14 & 20 & 16 & 20 \\
Sheep and Goat Pox (SGP) & 5 & 12 & 10 & 14 \\
Tick infestation/Lameness & 12 & 13 & 6 & 13 \\
Bloody urine/Babesiosis & 16 & 7 & 7 & 6 \\
Orf & 13 & 8 & - & - \\
Mangemites & 10 & 4 & 5 & 17 \\
Diarrhea syndrome & - & 6 & 11 & 5 \\
Anthrax/blackleg & - & - & 14 & - \\
Livefluke & - & - & 12 & 7 \\
Foot and Mouth Disease & - & 5 & 6 & - \\
Anaplasmosis & - & 5 & - & - \\
Bloat & 700 & 100 & 100 & 5 \\
Lice and fleas & - & 3 & - & - \\
Circling & - & 2 & - & - \\
Others & - & 5 & 4 & - \\
& & & & 5 \\
\hline
\end{tabular}

\section{Diseases of Sheep}

The top three ranked diseases of sheep were Diarrhea syndrome, respiratory syndrome and tick infestation/lameness in Chifra district. Lameness was mostly induced by ticks, but could be from thorny bush injury around hooves or footrot. Whereasthe most prioritized diseases of sheep in Ada'ar district were respiratory syndrome, tick infestation and SGP (Table 7). The informants believed that tick infestation predisposes for many diseases such as sandera (Orf), Agara (Mangemites), lameness and others. In Awash Fentale district, the informants ranked respiratory syndrome, diarrhea syndrome and SGP diseases as the top three priority diseases (Table 7).Vaccination against PPR was 
carried out in the same year 2012 in Ada'ar, Amibara and Awash-Fentaale districts.

Table 7: Rank of the most common diseases of sheep in selected districts.

\begin{tabular}{|c|c|c|c|c|}
\hline \multirow[b]{2}{*}{ List of Sheep diseases } & \multicolumn{4}{|c|}{ proportional piling with 100 stones } \\
\hline & Chifra & Ada'ar & Amibara & Awash-Fentale \\
\hline Diarrhea syndrome & 24 & 10 & 13 & 17 \\
\hline Broncho-Pneumonia synd. & 18 & 23 & 20 & 20 \\
\hline Tick infestation/Lameness & 16 & 16 & 12 & 13 \\
\hline Sheep and Goat Pox & 10 & 13 & 10 & 14 \\
\hline Sheep Pasteurollosis & 9 & 10 & - & 10 \\
\hline Anthrax/blackleg & - & - & 14 & 5 \\
\hline Liver fluke & - & - & 15 & - \\
\hline Bloody urine/Babesiosis & 7 & 3 & 5 & 5 \\
\hline Ceneorosis/circling & - & 7 & 6 & - \\
\hline Anaplasmosis & - & 5 & - & 3 \\
\hline Foot and Mouth Disease & - & 5 & - & 4 \\
\hline Bloat & 5 & 5 & - & - \\
\hline Orf & 4 & - & - & - \\
\hline Lice and fleas & 2 & - & - & 4 \\
\hline \multirow[t]{2}{*}{ Others } & 4 & 3 & 5 & 5 \\
\hline & 100 & 100 & 100 & 100 \\
\hline
\end{tabular}

The first three priority diseases for sheep in Amibara district were Respiratory syndrome (Resp. synd), Liver fluke and Anthrax/Malignant eodema. The informants distinguish the clinical manifestation of anthrax (Firah) and malignant eodema (Migda), but they often assume as the same origin and sometimes call them interchangeably. Visual observation during transect through grazing areas in Amibara district showed that a large concentration of different species animals were grazing in cotton plantation field after harvest and water canals for irrigation were traversing in the field which might be a potential risk factor for liver fluke, Anthrax and malignant eodema occurrences. 
PPR sero-positivity in the study population was high in all districts with an average sero-prevalence of 78\% (95\%CI: 74.4-81.6) (Table 8).Young age groups showed high sero-positivity than adult age groups (Table 9). Higher sero-positivity was observed in goats than in sheep. The sero-positivity against PPR might be acquired either due to natural disease which was possibly the case in Chifra district but prophylactic vaccination in the rest three districtswhich was conducted with the support of FAO and other NGO's operating in the region.

Table 8: Animal level Sero-positivity and 95\% CI of PPR in the studied districts.

\begin{tabular}{lcccccccc}
\hline $\begin{array}{l}\text { AFAR } \\
\text { wereda }\end{array}$ & capr & ovine & $\begin{array}{c}\text { \% pos. } \\
\text { Capr }\end{array}$ & $\begin{array}{c}\text { \% Pos. } \\
\text { Ovine }\end{array}$ & $\begin{array}{c}\text { Total } \\
\text { samples }\end{array}$ & $\begin{array}{c}\text { overall- } \\
\text { Pos (\%) }\end{array}$ & min & max \\
\hline CHIFRA & 65 & 65 & $93.8 \%$ & $73.8 \%$ & 130 & 83.1 & 76.6 & 89.5 \\
ADAAR & 62 & 58 & $74.2 \%$ & $69.0 \%$ & 124 & 71.0 & 63.0 & 79.0 \\
AMIBARA & 65 & 61 & $92.3 \%$ & $73.8 \%$ & 120 & 73.3 & 65.4 & 81.2 \\
AWASH F. & 66 & 58 & $75.8 \%$ & $65.5 \%$ & 126 & 84.1 & 77.7 & 90.5 \\
Total & 258 & 242 & $84.1 \%$ & $70.7 \%$ & 500 & 78.4 & 74.4 & 81.6 \\
\hline
\end{tabular}

Table 9: Sero-positivity of PPR in sheep and goats by age and sex in study districts

\begin{tabular}{llccc}
\hline Bio-data & Categories & Sample size & PPR positive & \% positive \\
\hline Age & Young & 64 & 53 & $\mathbf{8 2 . 8 1}$ \\
& Adult & 436 & 339 & $\mathbf{7 7 . 7 5}$ \\
\multirow{2}{*}{ Sex } & male & 23 & 12 & $\mathbf{5 2 . 1 7}$ \\
& Female & 477 & 380 & 79.66 \\
\multirow{2}{*}{ Species } & Sheep & 242 & 171 & $\mathbf{7 0 . 7} \%$ \\
& Goats & 258 & 217 & $\mathbf{8 4 . 1} \%$ \\
\hline
\end{tabular}

\section{Seasonality of disease occurrence}

The Community informant's unanimously defined four seasons in a year mainly marking a reference point at the rainy time.

1. Karma: (Kiremt) $=>$ (July and August) is the major rainy season

2. Dada'a: $=>$ (November, December, January) cold climate with light rain shower. 
3. Sugum: $=>$ (February, March, April) is dry season but not considered as drought if the rain comes during Dada'a.

4. Hagay: $=>$ (May- June) is dry and hot climate. If in case the rain during Dada'a season failed to rain, the dry season during Hagay become longer and they call the drought incidence as Gilal. Animals' particularly chronic disease affected onceand weak could die during such drought incidence. Informantsalso described the seasonal occurrence of diseases in their area (Table 10).

Table 10: Seasonal occurrence of sheep and goats diseases.

\begin{tabular}{|c|c|c|c|c|c|c|}
\hline Scientific Name & Vernacular name & Kerma & Dada'a & Sugum & Hagay & Remark \\
\hline Diarrhea synd./PPR & $\begin{array}{l}\text { Undahe,Wadar/Ili- } \\
\text { Biyak }\end{array}$ & & & ++ & ++ & \\
\hline SGP & Korboda & & ++ & ++ & + & All sn \\
\hline Ectoparasite & $\begin{array}{l}\text { Kilim, Enkata, } \\
\text { Kanadi, Agara }\end{array}$ & + & +++ & ++ & ++ & \\
\hline Diarrhea & Uruga & $+t$ & & & & \\
\hline S. Pasteurollosis & Dubbele & & & & ++ & \\
\hline Orf & Sandera & + & + & + & + & All sn \\
\hline CCPP & Gublo/ Mesengele & + & ++ & + & + & All sn \\
\hline Foot Rot & Kos/ Undufeta & +++ & & & & \\
\hline Bronchopneumonia & Goson/Surota & + & ++ & & & \\
\hline Bloat & Arabah/Funoyita & ++ & & & & \\
\hline Babesiosis & Abali/Asdaho & ++ & + & & & \\
\hline Heart water & Arawagit & & + & ++ & + & \\
\hline FMD & Abib & + & & & + & \\
\hline Fasciolaisis & Kirbi & & ++ & + & & \\
\hline
\end{tabular}

\section{Access to Veterinary Services}

The informants declared that in the past time when modern veterinary service wasn't accessible, they were dependent on traditional medicines prepared from different plant leaves, roots and other parts. But currently ranking of the informantsopinion showed that $>85 \%$ prefers to use modern clinics and less than $15 \%$ still use traditional medicines. They declared that Community animal health workers (CAHWs) and health postsare an immediate vet health service points to get help in their nearby locality. However, they use traditional medicines like branding, tobacoo, hot red pepper (Local name: Adangale) for some diseases. Adangale and tobacoo are added through the nostrils to open mucous 
blocked nostrils by lung worm infection (Goson/Surota). They use traditional medicinesin the following conditions:

- When they moved their long distance for grazing and could not access to clinics.

- When the animal got acute or peracute sickness which does not give time to reach at clinic like snake bite.

- The community still uses traditional medicine where clinics and health posts are far distant or are notyet functional to give service in their Kebele.

\section{Traditional Animal health information flow channel}

The informants underlined that they have good tradition of sharing animal health information called "Afar dagu" to transfer information and create awareness for other colleagues. When an outbreak occurs in the locality, pastorals and/or CAHWs report the case to the Vet health post personnel or chairman of the Kebele. Then if vaccination is required, official letter would be written to district Vet clinic. CAHWs in the Kebele could give treatment for some cases if they could manage at their scope. They also advise the owners to segregate sick animal from the herd/flock.

The staffs in local veterinary Clinic indicated that regular vet. service delivery reports starts at health post level and reported to the district clinic every monthly. However, the flow of the reports often suffer lack of clarityand irregularity which might besometimesdue to negligence, lack of awareness on the importance of reports and lack of timely response and feedback. In some districtsstandard OIE outbreak reporting format were not available and they use non standard formats to report outbreak occurrences.Moreover, some junior staffs had little exposure in filling the standard reporting format and requirestraining on how to fill correctly the formats.

\section{Veterinary infrastructure and manpower}

The number of veterinary clinics and health posts distributed in the four studied districts were 5 and 26 respectively. Veterinary manpower versus tropical livestock unit (TLU) in the study districts was approximately one veterinarian for 783,000 TLU and one paraprofessional for 20,000 TLU which indicated severe manpower shortage to deliver proper veterinary services. There were about 138 community animal health workers (CAHWs) distributed in $56 \mathrm{Ke}$ - 
beles. $(1 \mathrm{TLU}=$ Cattle $=1$, Ass $=0.5$, Horse $\&$ Mule $=0.8$ Sheep and goats $=0.1$, Camel=1.4 and Poultry=0.01 Source: FAO, 2004. The convert is based on $1 T L U$ is equivalent to $250 \mathrm{~kg}$ live weight of animal.)

\section{Discussion}

The current PDS study has enlightened the major disease problems in small ruminants. The ranking of livestock species in abundance and economic value indicated that small ruminants particularly goats are highly important for the livelihood of the pastoral community. Thus, it is so important that any development investment in the pastoral agricultural system should address the health problems of small ruminants.In this quick survey of goat's disease ranking, respiratory syndrome/CCPP, SGP and tick and tick borne diseases were among the priority ranked health problems. PPR outbreak was only seen in Chifra district, however prophylactic vaccination conducted in all other districts have suppressed the impact of PPR and because of this the informants didn't mentioned PPR as production constraints. This PDS information has enlightenedthe need for further detailed conventional epidemiological studies and disease control planning. Existing knowledge in the pastoral community could give valid information throughPDS that can be usedto design better animal health projects, delivery systems and more successful surveillance and control strategies (Jost et al., 2007, Catley and Birhanu Admassu, 2003).

The overall ranking of sheep diseases in the study districts showed that respiratory syndrome, diarrhea syndrome, tick infestation and SGP diseases were the most priority ranked health constraints. Among respiratory diseases lung worms, pneumonia and Septicemia pasteurellosis (Dubbele) were probably the most suspected diseases which require further conventional surveillance in the future. One of the limitations of our current participatory exercise was that the study has enabled to collect a broad list of small ruminant diseases to the knowledge of the informants but the scope and depth of the information generated was apparently shallowbecause of time limitation to use probing questions. The PDS result from Amibara district seems quite different from the rest other districts which might be due to different ecological condition related with irrigation farming and water logged swampy areas favorable for the occurrence of fascioliasis. 
Effective surveillance system should be sensitive, specific and timely. The sensitivity implies the capabilityof the system to detect the majority of events of interest (Mariner and Paskin, 2000). In this regard, the current PDS technique was sensitive to investigate and detect a large percentage of significant disease eventsoccurring in small ruminants. Existing veterinary knowledge in the pastoral community was so enthusiastic in identifying and describing the health problems encountered in their areas. But its specificity was limited because the judgment to ruleout some diseases based on clinical and gross pathology descriptions was difficult (Mariner and Paskin, 2000; Jostet al., 2007). Another strong side of the current PDS studywas that it was very timely in gathering action-oriented information whichlasted a total length of about two months. Thus, PDS method is a rapid,cheaper, more feasible method of obtainingactionoriented information than full-scale randomized surveys (Jostet al., 2007).It is often an attractive option for poorly-resourced veterinary services(Mariner and Paskin, 2000).

Small ruminants population were the highest number than other livestock species in the study areas whichmight be dictated due to the climate changes and erratic rainfall distribution in the arid area.The pastorals are inclined more towards the production of small ruminants which are relatively more tolerant to meager feed resources than cattle(Jacob Aklilu,and Catley 2010). Small ruminants constitute a large component of the livelihood of pastorals in terms of their economic importance and social values. They are the source of easily accessible cash income for their daily needs and alsokeep as a capital asset. Small ruminants are also source of milk and meat source for the family, and also used for various social values. Given the present rapid population growth, urbanization and slow income growth in the pastoral community, small ruminant production plays a pivotal role to support the livelihood and food security of the family because of their fast reproductive turn-over (Markos Tibbo, 2006).

Afar regional state has established many veterinary service delivery structures in the study districts. However, the quality and extent of service delivery systems were still at infant stage yet to mitigate the disastrous effect of livestock diseases. Taking into account the real gaps faced in disease reporting and timely response in outbreak control measures, it is imperative to establish appropriate networking system across all levels of the veterinary services of the region to controltheoutbreak occurrences. Timely responses are necessary to avert the damage due to outbreak incidences. Moreover, the standard 
outbreak reporting formatsshould be availed toall districts and the veterinary staffs newly recruitedat the district level shouldbe familiarized with how to fill the standard reporting formatto improve the quality and frequency of reporting.

High sero-prevalence of PPR in the studied population showed that the seroconversion was either due to exposure to the natural PPR infection or vaccination immunity.This showed that the efforts made to control PPR through vaccination by the government of Afar Regional State, and NGOs have attained effective level of protective immunity to control the disease in a population. Sero-prevalence differences observed between species and age groups might have come due to the natural resistance and exposure to the PPR virus.

\section{Conclusion}

This study has enlightenedmajor small ruminant disease problems for further epidemiological and ecological studies to generate information used for the future control endeavor.

\section{Acknowledgement}

We would be grateful to FAO Ethiopia for financial support through OSRO/ RAF/113/FRA project, under LOA Ref. FAO/DRAM/LOA36/12. We would like to extend our thanks to Afar Regional Pastoral Agriculture Bureau and district pastoral Agriculture offices in which this PDS work was conducted for their keen supports to effectively accomplish the study. We would like to appreciate the coordination and technical assistance offered by Ato EndaykefagneYirga, Ato Mohammed Ali, Dr Misrak Alemu and Ato Merga Mammo during field work in their respective districts.

\section{References}

Hirpa, A. and Abebe, G., 2008.Economic Significance of Sheep and Goats; In: AlemuYami and R.C. Merkel (Ed) Sheep and Goat Production Handbook for Ethiopia, e-book, http://www.esgpip.org/HandBook/Chapter1.html.

Aklilu, Y. and Catley, A.,2010.Livestock Exports fromPastoralist Areas:An Analysis of Benefits by Wealth Group and Policy Implications. IGAD livestock Policy Initiative, Working paper 01-10, January, 2010. 
Catley, A. and Admassu, B., 2003. Using participatory Epidemiology to assess the impact of livestock diseases. FAO-OIE-AU/IBAR-IAEA Consultative group meeting on CBPP in Africa, 12-14 Nov 2003, FAO Head quarter, Italy Rome.

Anonymous, 2011. Annual year book of Epidemiology, Animal and Plant Health Regulatory Directorate, Ministry of Agriculture.

CSA, 2012. Agricultural sample survey 2011/2012, Report on livestock and livestock characteristics. Central Statistical Agency of Ethiopia.

ILCA, 1993.Handbook of African Livestock Statistics. International Livestock Center for Africa, Addis Ababa.

Jost, C., Mariner, C., Roeder, P., Sawitri, E., and Macgregor-SkinnerG.J., 2007.Participatory epidemiology in disease surveillance and research.Rev. sci. tech. Off.int. Epiz., 26 (3), 537-547.

Mariner, J.C, and Paskin, R., 2000.Manual on Participatory Epidemiology- Method for the collection of action-Oriented epidemiological intelligence, FAO Animal Health manual 10, Rome.

Tibbo, M., 2006.Productivity and Health of Indigenous Sheep breeds and crossbreds in the Central Ethiopian Highlands. Swedish University of Agricultural Sciences, Uppsala, PhD Thesis.

USAID, 2011. Ethiopia Sanitary and Phytosanitary Standards and Livestock and Meat Marketing Programme. Final report: Norman Borlaug Institute for International Agriculture of the Texas A andM University System. Addis Ababa, Ethiopia. 